\title{
An In Vitro Comparison of PMMA and Calcium Sulfate as Carriers for the Local Delivery of Gallium(III) Nitrate to Staphylococcal Infected Surgical Sites
}

\author{
Rebecca A. Garcia, David J. Tennent, David Chang, \\ Joseph C. Wenke, and Carlos J. Sanchez Jr.
}

Extremity Trauma and Regenerative Medicine, United States Army Institute of Surgical Research, JBSA Fort Sam, Houston, TX, USA

Correspondence should be addressed to Carlos J. Sanchez Jr.; sanchezcj@livemail.uthscsa.edu

Received 2 July 2015; Accepted 24 December 2015

Academic Editor: Giuseppe Cama

Copyright ( $) 2016$ Rebecca A. Garcia et al. This is an open access article distributed under the Creative Commons Attribution License, which permits unrestricted use, distribution, and reproduction in any medium, provided the original work is properly cited.

\begin{abstract}
Antibiotic-loaded bone cements, including poly(methyl methacrylate) (PMMA) and calcium sulfate $\left(\mathrm{CaSO}_{4}\right)$, are often used for treatment of orthopaedic infections involving Staphylococcus spp., although the effectiveness of this treatment modality may be limited due to the emergence of antimicrobial resistance and/or the development of biofilms within surgical sites. Gallium(III) is an iron analog capable of inhibiting essential iron-dependent pathways, exerting broad antimicrobial activity against multiple microorganisms, including Staphylococcus spp. Herein, we evaluated PMMA and $\mathrm{CaSO}_{4}$ as carriers for delivery of gallium(III) nitrate $\left(\mathrm{Ga}\left(\mathrm{NO}_{3}\right)_{3}\right)$ to infected surgical sites by assessing the release kinetics subsequent to incorporation and antimicrobial activity against S. aureus and S. epidermidis. $\mathrm{PMMA}$ and to a lesser extent $\mathrm{CaSO}_{4}$ were observed to be compatible as carriers for $\mathrm{Ga}\left(\mathrm{NO}_{3}\right)_{3}$, eluting concentrations with antimicrobial activity against planktonic bacteria, inhibiting bacterial growth, and preventing bacterial colonization of beads, and effective against established bacterial biofilms of S. aureus and S. epidermidis. Collectively, our in vitro results indicate that PMMA is a more suitable carrier compared to $\mathrm{CaSO}_{4}$ for delivery of $\mathrm{Ga}\left(\mathrm{NO}_{3}\right)_{3}$; moreover they provide evidence for the potential use of $\mathrm{Ga}\left(\mathrm{NO}_{3}\right)_{3}$ with PMMA as a strategy for the prevention and/or treatment for orthopaedic infections.
\end{abstract}

\section{Introduction}

Orthopaedic related postoperative infections are a serious complication contributing to the increased overall healthcare associated costs as well as patient associated morbidity [14]. For traumatic open lower extremity fractures, infectious complications occur in up to as many as $64 \%$ of patients and is a significant factor contributing to increased rates of surgical revisions, time to osseous union, and extremity amputation [5-8]. While the vast majority of orthopaedic related infections involve Gram positive bacteria, including methicillin resistant Staphylococcus aureus (MRSA) and Staphylococcus epidermidis [9], infections due to Gram negative bacteria have also been described in particular for traumatic orthopaedic injuries $[6,10]$. Of note, the majority of bacteria responsible for these infections display resistance to a number of the commonly used antibiotics for treatment, further complicating the clinical management $[6,10-12]$.
The current standard of care for the majority of orthopaedic related wound infections is a combination of surgical management and systemic antibiotics, often with the addition of local antimicrobial therapy [2, 3, 13-15]. Controlled release of local antibiotics to infected surgical sites is typically achieved using nonabsorbable or absorbable carriers such as poly(methyl methacrylate) (PMMA) and calcium sulfate, respectively $[13,16,17]$. The most common antimicrobials loaded in bone cements include broad spectrum aminoglycosides, such as gentamicin and tobramycin, and/or the glycopeptide, vancomycin. While PMMA beads are traditionally used for local antibiotic delivery, the variability of antimicrobial elution from these materials, the limited compatibility due to the exothermic polymerization of the material, and the requirement of a secondary surgery for removal have led to more frequent clinical use of absorbable materials including calcium sulfate $[1,18,19]$. Importantly, despite the success associated with use of this treatment 
modality, the emergence of antimicrobial resistance amongst organisms as well as biofilm formation has been reported to reduce the effectiveness of this intervention $[4,20]$, highlighting the need for use of alternative agents to address this growing clinical challenge.

The acquisition of ferric iron(III) (Fe(III)) from the surrounding environment is critical to normal bacterial physiology and virulence. However, ferric iron bioavailability in soft tissues is normally kept at extremely low levels $\left(<10^{-18} \mathrm{M}\right)$ as a part of an immune defense against invading pathogens [21]. In response to the low availability of iron, bacteria have evolved numerous strategies enabling iron acquisition $[22,23]$. Given this pivotal role of iron, there have been numerous studies evaluating the potential of iron modulation as an alternative method of antimicrobial therapy [24-27]. In particular, the nonreducible iron analog, gallium(III), commonly used as the salt gallium(III) nitrate $\left(\left(\mathrm{GaNO}_{3}\right)_{3}\right)$ and the active component of the previously FDA approved drugs used for treating bone loss disorders such as Paget's and hypercalcemia [28-30], has been shown to have broad antimicrobial activity against both Gram negative and Gram positive species, including Staphylococcus spp. [25, 26, 31-33]. Given the chemical similarity of gallium(III) to ferric iron, gallium can effectively compete with, bind, and inhibit the activity of iron-dependent enzymes exerting strong antimicrobial activity [24,25]. As iron has been shown to be essential to bacterial growth and virulence, and moreover to modulate biofilm formation in vitro, use of $\mathrm{Ga}\left(\mathrm{NO}_{3}\right)_{3}$ may represent an effective strategy for the prevention and treatment of infections. While there have been studies demonstrating the successes of intravenous use of $\mathrm{Ga}\left(\mathrm{NO}_{3}\right)_{3}$ for the treatment of systemic bacterial infections $[34,35]$, to our knowledge there are no studies to date that have evaluated the use of $\mathrm{Ga}\left(\mathrm{NO}_{3}\right)_{3}$ for treatment of orthopaedic related infections.

As antibiotic-loaded PMMA and calcium sulfate have been traditionally used as preventative and treatment strategies for orthopaedic related infections, the purpose of this study was to determine whether PMMA and/or $\mathrm{CaSO}_{4}$ could be used as carriers for local delivery to infected surgical sites by assessing the release kinetics and evaluating antimicrobial activity against planktonic and biofilm derived staphylococci in vitro.

\section{Materials and Methods}

2.1. Reagents. Gallium(III) nitrate $\left(\left(\mathrm{GaNO}_{3}\right)_{3}\right)$ was purchased from Sigma-Aldrich (St. Louis, MO) and prepared for use in the experimental assays according to the manufacturer's recommendations.

2.2. Bacterial Strains and Culture Conditions. In this study commercially available strains from the American Type Culture Collection (ATCC, Manassas, VA, USA), including Staphylococcus aureus ATCC 29213 and Staphylococcus epidermidis ATCC 12228 were used. Bacterial strains were cultured on Mueller-Hinton Agar Plates (Remel, Lenexa, KS, USA) or in Cation-adjusted Mueller-Hinton broth (MHB II) at $37^{\circ} \mathrm{C}$.
2.3. Preparation of Poly(methyl methacrylate) (PMMA) and Calcium Sulfate Beads. PMMA beads loaded with 2.4\%, $4.7 \%, 9.09 \%$, and $13 \% \mathrm{Ga}\left(\mathrm{NO}_{3}\right)_{3}$ were made by combining $40 \mathrm{~g}$ PALACOS R Radiopaque bone cement powder (Zimmer Orthopaedic Surgical Products, Dover, OH, USA) with $0.983 \mathrm{~g}, 1.98 \mathrm{~g}, 3.9 \mathrm{~g}$, and $5.8 \mathrm{~g}$ of $\mathrm{Ga}\left(\mathrm{NO}_{3}\right)_{3}$ powder, respectively. Methyl methacrylate monomer $(20 \mathrm{~mL})$ was added to the powder, mixed thoroughly, and spread across a $3 \mathrm{~mm}$ mold, creating beads weighing approximately $20 \mathrm{mg}$ each. For the preparation of $\mathrm{Ga}\left(\mathrm{NO}_{3}\right)_{3}$ loaded calcium sulfate beads at similar concentrations, $10 \mathrm{cc}$ bone cement (Osteoset Resorbable Mini-Bead Kit, Wright Medical Technology, Inc., Netherlands) was mixed with $0.246 \mathrm{~g}, 0.492 \mathrm{~g}, 0.99 \mathrm{~g}$, and $1.46 \mathrm{~g}$, respectively. $\mathrm{CaSO}_{4}$ beads were casted using the $3 \mathrm{~mm}$ molds as described as above. A qualitative assessment on the effect of $\mathrm{Ga}\left(\mathrm{NO}_{3}\right)_{3}$ loading on the curing time of PMMA and $\mathrm{CaSO}_{4}$ beads was performed by testing the firmness of the materials over time relative to beads loaded with a clinically relevant amount of the glycopeptide, vancomycin $(2.4 \% \mathrm{w} / \mathrm{w})[1,36]$. This comparison was primarily performed to demonstrate the effect of $\mathrm{Ga}\left(\mathrm{NO}_{3}\right)_{3}$ to increase curing time which could limit its potential clinical utility, given that antibiotic loaded beads are typically prepared during surgical procedures.

2.4. $\mathrm{Ga}\left(\mathrm{NO}_{3}\right)_{3}$ Release Kinetics. For collection of eluents from the $\mathrm{Ga}\left(\mathrm{NO}_{3}\right)_{3}$ loaded PMMA and calcium sulfate, beads (three/group) were placed into $2 \mathrm{~mL}$ of PBS and incubated at $37^{\circ} \mathrm{C}$ as previously described $[18,37]$. Eluents were removed daily, collected, and tubes containing beads were replenished with fresh PBS daily for up to 7 days. The collected eluents were stored at $-80^{\circ} \mathrm{C}$ until use.

Quantification of gallium (Ga) was accomplished using Inductively Coupled Plasma Mass Spectrometry (ICP-MS) of acid digested samples. Briefly, $150 \mu \mathrm{L}$ BDH Aristar Plus Nitric Acid (70\%, VWR Scientific, Radnor, PA, USA) was added to metal-free $15 \mathrm{~mL}$ conical tubes, followed by $150 \mu \mathrm{L}$ sample. Samples were then heated at $80^{\circ} \mathrm{C}$ for 4 hours followed by addition of ultrapure $\mathrm{H}_{2} \mathrm{O}(18.2 \mathrm{M} \Omega \cdot \mathrm{cm})$ and multielement internal standard containing $\mathrm{Bi}, \mathrm{Ho}, \mathrm{In}, 6 \mathrm{Li}$, Sc, Tb, and Y (CLISS-1, Spex CertiPrep, Metuchen, NJ, USA) to produce a final solution of $3 \%$ nitric acid (v/v) and $1 \mathrm{ng} / \mathrm{mL}$ internal standard in a total sample volume of $5 \mathrm{~mL}$. Individual $\mathrm{Ga}$ elemental standards were prepared by diluting a $1000 \mu \mathrm{g} / \mathrm{mL}$ of certified Ga standard (Inorganic Ventures, Christiansburg, VA, USA) to $10 \mu \mathrm{g} / \mathrm{mL} \mathrm{Ga}$. Ga standards were then made via $1 / 2$ serial dilutions to obtain 9 elemental standards and a blank. All standards contained $3 \%$ nitric acid $(\mathrm{v} / \mathrm{v})$ and $1 \mathrm{ng} / \mathrm{mL}$ internal standard up to a total sample volume of $5 \mathrm{~mL}$. ICP-MS was performed on a computer-controlled (Qtegra software v. 2.4) Thermo iCap Qc ICP-MS (Thermo Fisher Scientific, Waltham, MA, USA) operating in standard mode and equipped with a CETAC 260 Autosampler (Omaha, NE, USA). Each sample was acquired using a $35 \mathrm{sec}$ uptake and $90 \mathrm{sec}$ washout time (rinse was 3\% Aristar Plus $\mathrm{HNO}_{3}$ (v/v)), 1 survey run (3 sweeps, 10 ms dwell time), and 3 main (peak jumping) runs (100 sweeps, $100 \mathrm{~ms}$ dwell time). The isotopes selected for analysis were 
$69,71 \mathrm{Ga}$, with $89 \mathrm{Y}$ and $115 \mathrm{In}$ chosen as internal standards for data interpolation. Instrument performance is optimized daily through autotuning followed by verification. Absolute values of gallium $[\mu \mathrm{M}]$ as well as the cumulative release over time, as expressed as percentage released from the total original loaded amount into $\mathrm{PMMA}$ or $\mathrm{CaSO}_{4}$, were plotted.

2.5. Antimicrobial Activity $\mathrm{Ga}\left(\mathrm{NO}_{3}\right)_{3}$ against Planktonic Bacteria. The inhibitory concentration of $\mathrm{Ga}\left(\mathrm{NO}_{3}\right)_{3}$ was determined using a modified version of the broth microdilution assay in 96-well round bottom plates as previously described $[18,20,34,35]$. In brief, bacteria were grown in MHB II broth to an optical density $(600 \mathrm{~nm})$ of $0.1\left(\sim 10^{8} \mathrm{CFU} / \mathrm{mL}\right)$, washed, and resuspended in diluted MHB II $(0.3 \mathrm{~g} / \mathrm{L})$ broth to a final bacterial concentration of $10^{6} \mathrm{CFU} / \mathrm{mL}$. One hundred microliters was then transferred to individual wells of a round bottom plate $\left(\sim 10^{5} \mathrm{CFU} /\right.$ well $)$, containing $100 \mu \mathrm{L}$ of $\mathrm{Ga}\left(\mathrm{NO}_{3}\right)_{3}$ at increasing concentrations, $0.25-512 \mu \mathrm{M}$, diluted in MHB II $(0.3 \mathrm{~g} / \mathrm{L})$ broth at a $2 \mathrm{x}$ concentration. Bacteria were incubated overnight at $37^{\circ} \mathrm{C}$ under static conditions, and following overnight incubation, the optical densities $\left(A_{600 \mathrm{~nm}}\right)$ were measured.

2.6. Use of $\mathrm{Ga}\left(\mathrm{NO}_{3}\right)_{3}$ Loaded PMMA and $\mathrm{CaSO}_{4}$ Beads to Inhibit Bacterial Growth in Broth. To evaluate the antimicrobial ability of $\mathrm{Ga}\left(\mathrm{NO}_{3}\right)_{3}$ loaded beads at the various concentrations against planktonic bacteria in broth cultures, beads (3/group) were added to sterile $15 \mathrm{~mL}$ conical tubes containing $5 \mathrm{~mL}$ of a bacterial culture adjusted to $10^{6} \mathrm{CFU} / \mathrm{mL}$ in MHB II $(0.3 \mathrm{~g} / \mathrm{L})$ broth. Cultures containing the $\mathrm{Ga}\left(\mathrm{NO}_{3}\right)_{3}$ beads were coincubated at $37^{\circ} \mathrm{C}$ with agitation for up to 7 days, with cultures removed and exchanged every 24 hours. At days 1, 3, and 7, $100 \mu \mathrm{L}$ was removed and bacterial viability within cultures was determined by plating serial dilutions onto MHB agar plates. As a control group for the experiment, unloaded (0.0\%) PMMA and $\mathrm{CaSO}_{4}$ beads were used. Data was represented as the $\log$ reduction relative to a bacterial culture grown in MHB II $(0.3 \mathrm{~g} / \mathrm{L})$ broth without PMMA or $\mathrm{CaSO}_{4}$ beads.

2.7. Bacterial Colonization of $\mathrm{Ga}\left(\mathrm{NO}_{3}\right)_{3}$ Loaded PMMA and $\mathrm{CaSO}_{4}$ Beads. To evaluate the effect of $\mathrm{Ga}\left(\mathrm{NO}_{3}\right)_{3}$ loading on the bacterial colonization of PMMA and $\mathrm{CaSO}_{4}$ beads simultaneously with elution, $\mathrm{Ga}\left(\mathrm{NO}_{3}\right)_{3}$ loaded and unloaded beads (6/well) were placed into 6 -well plates and cultured up to 7 days as previously described [20]. Briefly, $4 \mathrm{~mL}$ of MHB II broth, $0.3 \mathrm{~g} / \mathrm{L}$, containing $10^{6} \mathrm{CFU} / \mathrm{mL}$ of bacteria was added to the individual wells containing the PMMA or $\mathrm{CaSO}_{4}$ beads containing the increasing concentrations of $\mathrm{Ga}\left(\mathrm{NO}_{3}\right)_{3}$. Every 24 hours, broth cultures were removed and replaced with fresh bacterial cultures exposing the beads to continuous bacterial challenge. At days 1, 3, and 7, beads were removed from plates, washed with sterile $1 \mathrm{x}$ PBS, and placed into individual wells of a 96-well plate, and the plates containing beads were sonicated to remove attached bacteria. The number of viable bacteria removed from beads was determined by plating serial dilutions onto MHB agar plates as previously described [38].
2.8. Activity of $\mathrm{Ga}\left(\mathrm{NO}_{3}\right)_{3}$ Loaded Beads on Established Bacterial Biofilms. Biofilms were developed and evaluated for susceptibility to $\mathrm{Ga}\left(\mathrm{NO}_{3}\right)_{3}$ using the minimum biofilm eradication concentration (MBEC) P\&G plates (Innovotech, Alberta, Canada) as previously described with some minor modifications [38-40]. In brief, $180 \mu \mathrm{L}$ of bacteria diluted to $10^{6} \mathrm{CFU} / \mathrm{mL}$ was added to individual wells of the MBEC plates and incubated for 48 hours at $37^{\circ} \mathrm{C}$ with shaking at $150 \mathrm{rpm}$ (VWR, Radnor, PA, USA). Following incubation, the plate tops containing the pegs with established biofilms were rinsed in sterile $1 \mathrm{x}$ PBS, placed in a challenge plate containing either $\mathrm{Ga}\left(\mathrm{NO}_{3}\right)_{3}, 0.25-512 \mu \mathrm{M}$, or $\mathrm{Ga}\left(\mathrm{NO}_{3}\right)_{3}$ loaded beads $(2.4-13 \%)$ in MHB II $(0.3 \mathrm{~g} / \mathrm{L})$ broth and incubated for an additional 24 hours. After treatment, pegs were then rinsed and sonicated for 15 minutes at $40 \mathrm{kHz}$ (Branson Ultrasonics Corp., Danbury, CT, USA) into a 96-well plate containing PBS. Bacterial viability was determined by plating serial dilutions onto MHB agar plates.

2.9. Statistical Analysis. Where appropriate, statistical analysis was performed using an unpaired Student $t$-test or a one-way ANOVA with Dunnett's post hoc evaluation for comparison of the control group between multiple treatment groups. Values of $p<0.05$ were considered to be statistically significant. All experimental assays were performed in triplicate.

\section{Results}

3.1. Activity of $\mathrm{Ga}\left(\mathrm{NO}_{3}\right)_{3}$ on Planktonic Culture and Established Biofilms of S. aureus and S. epidermidis. Initial testing of the effect of $\mathrm{Ga}\left(\mathrm{NO}_{3}\right)_{3}$ on planktonic growth of $S$. aureus ATCC 29213 and S. epidermidis ATCC 12228 was performed using a modified version of the broth microdilution assay in iron deplete media to assess antimicrobial activity and ensure bacterial susceptibility of the strains used in the study. Antimicrobial activity of $\mathrm{Ga}\left(\mathrm{NO}_{3}\right)_{3}$ on planktonic, that is, culture grown, bacteria was observed to be both strainand concentration-dependent with significant decreases in bacterial growth at concentrations $\geq 16 \mu \mathrm{M}$ and $\geq 4 \mu \mathrm{M}$ for $S$. aureus and $S$. epidermidis, respectively (Figure 1(a)). Notably, concentrations of $\mathrm{Ga}\left(\mathrm{NO}_{3}\right)_{3} \geq 64 \mu \mathrm{M}$ were observed to completely inhibit bacterial growth of both strains tested. In addition to the activity on planktonic bacteria, $\mathrm{Ga}\left(\mathrm{NO}_{3}\right)_{3}$ was also observed to have antimicrobial activity against biofilms of $S$. aureus and $S$. epidermidis, albeit at much higher concentrations, $\geq 128 \mu \mathrm{M}$ and $\geq 256 \mu \mathrm{M}$, respectively, compared to their planktonic counterparts (Figure 1(b)).

3.2. In Vitro Release of $\mathrm{Ga}\left(\mathrm{NO}_{3}\right)_{3}$ from $\mathrm{PMMA}$ and $\mathrm{CaSO}_{4}$. To evaluate the potential use of $\mathrm{PMMA}$ and $\mathrm{CaSO}_{4}$ as carriers for $\mathrm{Ga}\left(\mathrm{NO}_{3}\right)_{3}$ we evaluated the effect of loading various concentrations on the curing time of these materials; moreover we characterized the release kinetics of gallium(III) over time. Incorporation of $\mathrm{Ga}\left(\mathrm{NO}_{3}\right)_{3}$ into PMMA at concentrations $\geq 9.09 \%$ (w/w) extended the time for the curing of PMMA roughly up to 1 hour compared to the approximately $\sim 15$ minutes required for curing of vancomycin loaded PMMA 


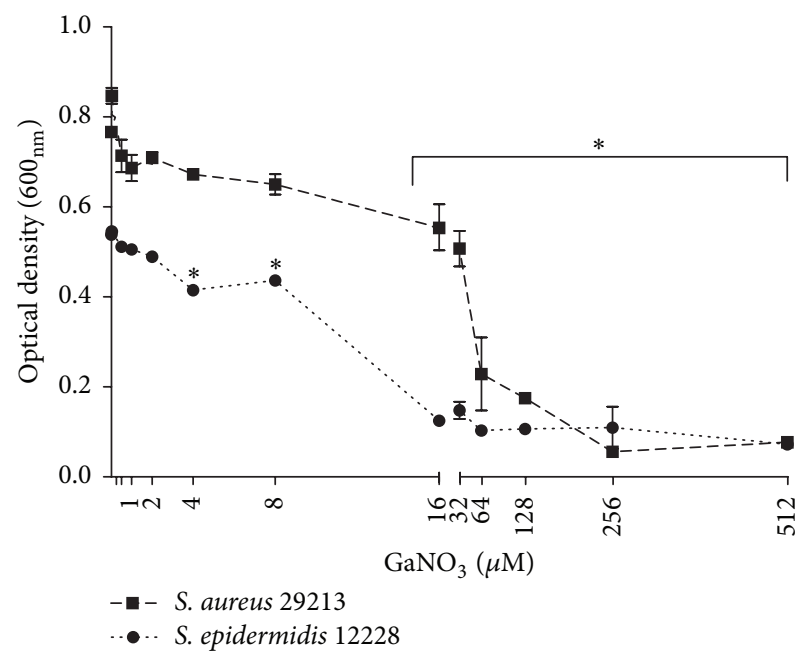

(a)

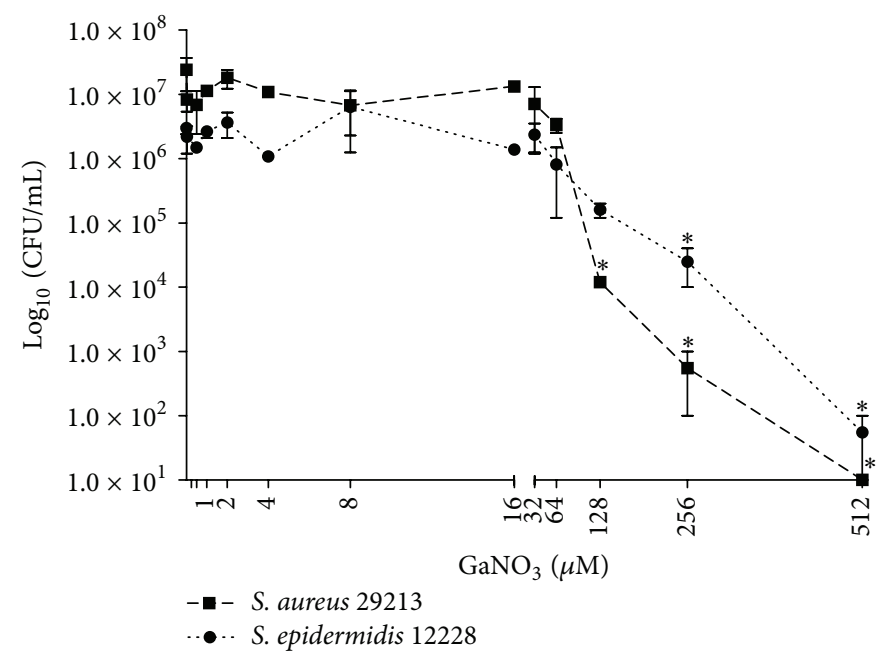

(b)

FIGURE 1: In vitro antimicrobial activities of $\mathrm{Ga}\left(\mathrm{NO}_{3}\right)_{3}$. Activity of $\mathrm{Ga}\left(\mathrm{NO}_{3}\right)_{3}, 0.5-512 \mu \mathrm{M}$, against planktonic bacteria (a) and biofilms (b) of Staphylococcus epidermidis ATCC 12228 and Staphylococcus aureus ATCC 29213 following overnight exposure to increasing concentrations, in MHB II ( $0.3 \mathrm{~g} / \mathrm{L})$ broth in 96 -well plates. Data is representative of mean \pm SD of three independent experiments. Statistical analysis was performed using Student's $t$-test; $*$ indicates $p<0.05$ relative to the untreated control group; Student's $t$-test.

$(2.4 \% \mathrm{w} / \mathrm{w})$. Of note, while the PMMA beads were not completely cured, even after $30 \mathrm{~min}$, the material was workable and maintained structural integrity with handling. In contrast to PMMA, incorporation of $\mathrm{Ga}\left(\mathrm{NO}_{3}\right)_{3}$ into $\mathrm{CaSO}_{4}$ up to the $13 \%(\mathrm{w} / \mathrm{w})$ was not observed to have any impact on the curing time, relative to beads loaded with vancomycin.

Release of $\mathrm{Ga}\left(\mathrm{NO}_{3}\right)_{3}$ from both PMMA and $\mathrm{CaSO}_{4}$ was characterized by a rapid initial release followed by slower sustained release. $\mathrm{Ga}\left(\mathrm{NO}_{3}\right)_{3}$ release from PMMA had a large initial burst, releasing 55\%, 34\%, 19\%, and $22 \%$ of the total amount loaded within the first day and reaching mean concentrations of $470 \pm 9,592 \pm 11,636 \pm 10$, and $1149 \pm 11 \mu \mathrm{M}$, for the $2.4 \%, 4.7 \%, 9.09 \%$, and $13 \%(\mathrm{w} / \mathrm{w})$, respectively (Figures 2(a) and 2(c)). After this initial burst, elution of $\mathrm{Ga}\left(\mathrm{NO}_{3}\right)_{3}$ was much lower and sustained for up to 7 days releasing $59 \%, 37 \%, 23 \%$, and $25 \%$ and reaching mean levels of $6 \pm 5,5 \pm 3,7 \pm 4$, and $14 \pm 5 \mu \mathrm{M}$, for $2.4 \%, 4.7 \%, 9.09 \%$, and $13 \%(\mathrm{w} / \mathrm{w})$, respectively. Similarly, $\mathrm{Ga}\left(\mathrm{NO}_{3}\right)_{3}$ release from $\mathrm{CaSO}_{4}$ also had a large initial burst releasing $21 \%, 26 \%, 28 \%$, and $28 \%$ within the first day and reaching mean concentrations of $178 \pm 13,458 \pm 11,929 \pm 13$, and $1488 \pm 15 \mu \mathrm{M}$, for $2.4 \%, 4.7 \%, 9.09 \%$, and $13 \%(\mathrm{w} / \mathrm{w})$, respectively (Figures $2(\mathrm{~b})$ and $2(\mathrm{~d}))$. $\mathrm{Ga}\left(\mathrm{NO}_{3}\right)_{3}$ release from $\mathrm{CaSO}_{4}$ was detected up to the 7 days evaluated, releasing $39 \%$, $39 \%, 35 \%$, and $36 \%$, and reaching mean levels of $21 \pm 4,16 \pm 3$, $13 \pm 3$, and $17 \pm 8 \mu \mathrm{M}$, for $2.4 \%, 4.7 \%, 9.09 \%$, and $13 \%(\mathrm{w} / \mathrm{w})$, respectively.

3.3. Inhibitory Activity of $\mathrm{Ga}\left(\mathrm{NO}_{3}\right)_{3}$ Loaded PMMA and $\mathrm{CaSO}_{4}$ Beads. To evaluate the antimicrobial activity against S. aureus and S. epidermidis, bacterial cultures were exposed to PMMA or $\mathrm{CaSO}_{4}$ beads loaded with either $2.4 \%, 4.7 \%$, $9.09 \%$, or $13 \%(\mathrm{w} / \mathrm{w}) \mathrm{Ga}\left(\mathrm{NO}_{3}\right)_{3}$ in diluted MHB II broth (Figure 3). Control (empty; 0.0\%) PMMA and $\mathrm{CaSO}_{4}$ beads were not observed to have any antimicrobial activity against either of the two strains tested. In contrast, the $\mathrm{Ga}\left(\mathrm{NO}_{3}\right)_{3}$ loaded PMMA beads had antimicrobial activity against both S. aureus and S. epidermidis over time (Figures 3(a) and 3(b)). Against $S$. aureus, incorporation of $\mathrm{Ga}\left(\mathrm{NO}_{3}\right)_{3}$ into PMMA at $2.4 \%-4.7 \%(\mathrm{w} / \mathrm{w})$ was associated with a $4-$ to $6-\log$ reduction during the first three days, whereas no significant antimicrobial activity was observed by day 7 . Incorporation of $\mathrm{Ga}\left(\mathrm{NO}_{3}\right)_{3}$ into PMMA at concentrations of $9.09 \%-13 \%$ (w/w) had the most dramatic effects reducing bacterial cultures between 6- and 10-logs during the first day, with $\geq 3$ $\log$ reductions up to 7 days (Figure 3(a)). Interestingly, for $S$. epidermidis, exposure to $\mathrm{Ga}\left(\mathrm{NO}_{3}\right)_{3}$ loaded beads at all of the concentrations tested was observed to have a much greater effect, reducing bacterial cultures, between 4- and 6-log reduction, up to the 7 days evaluated (Figure 3(b)). Similar to the PMMA beads, loading of $\mathrm{Ga}\left(\mathrm{NO}_{3}\right)_{3}$ into $\mathrm{CaSO}_{4}$ was also observed to have antimicrobial activity against $S$. aureus and S. epidermidis (Figures 3(c) and 3(d)). The antimicrobial effect of $\mathrm{Ga}\left(\mathrm{NO}_{3}\right)_{3}$ loaded $\mathrm{CaSO}_{4}$ was also dependent on the total loaded concentration for S. aureus, albeit only the higher concentrations of $\mathrm{Ga}\left(\mathrm{NO}_{3}\right)_{3}$ loading, between 9.09 and $13.0 \%$ (w/w), were observed to achieve better bacterial reductions, whereas the lower concentrations, $2.4-4.7 \%$ (w/w), had less of an effect (Figure 3(c)), which likely reflect the lower levels of $\mathrm{Ga}\left(\mathrm{NO}_{3}\right)_{3}$ released at the later time points. In contrast to the effect observed with gallium loaded PMMA, antimicrobial activity against $S$. epidermidis was much more variable, with significant antimicrobial activity observed for beads loaded with $\geq 4.7 \%$ (w/w) (Figure 3(d)).

3.4. Effect of $\mathrm{Ga}\left(\mathrm{NO}_{3}\right)_{3}$ Loading on Bacterial Colonization of PMMA and $\mathrm{CaSO}_{4}$ Beads. Due to the associations between 


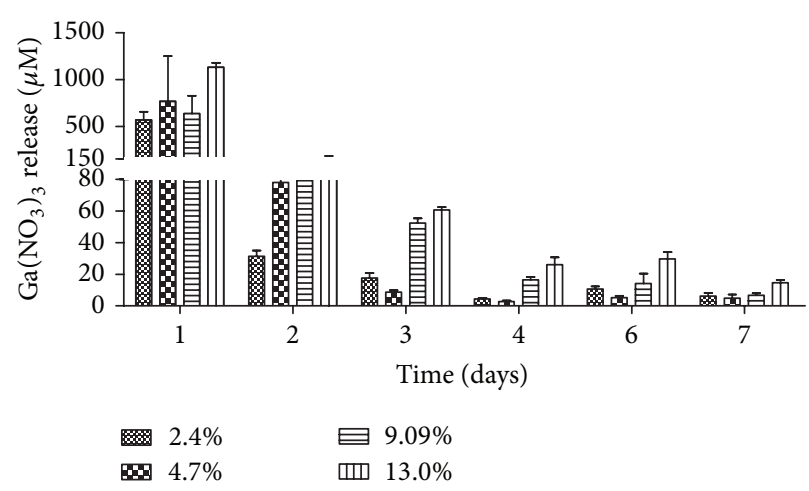

(a)

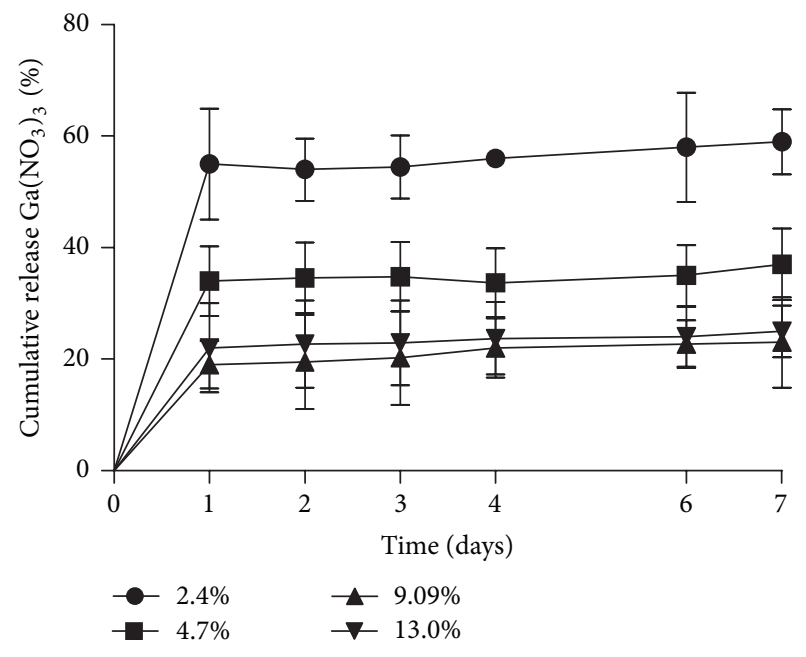

(c)

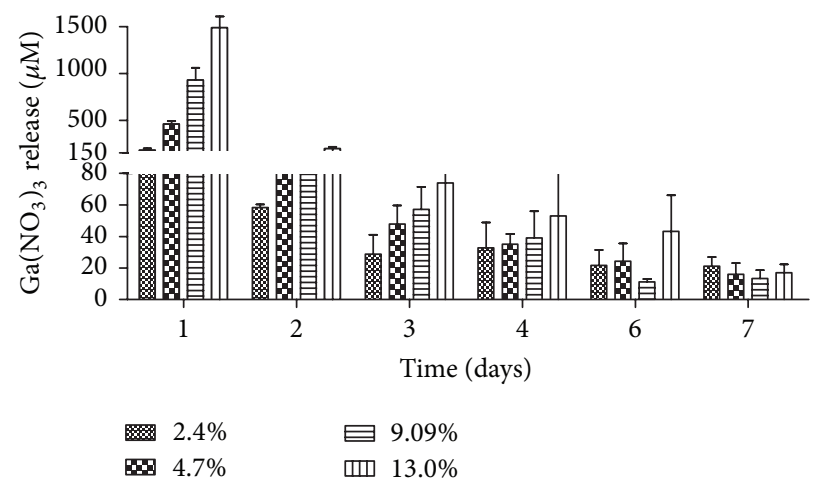

(b)

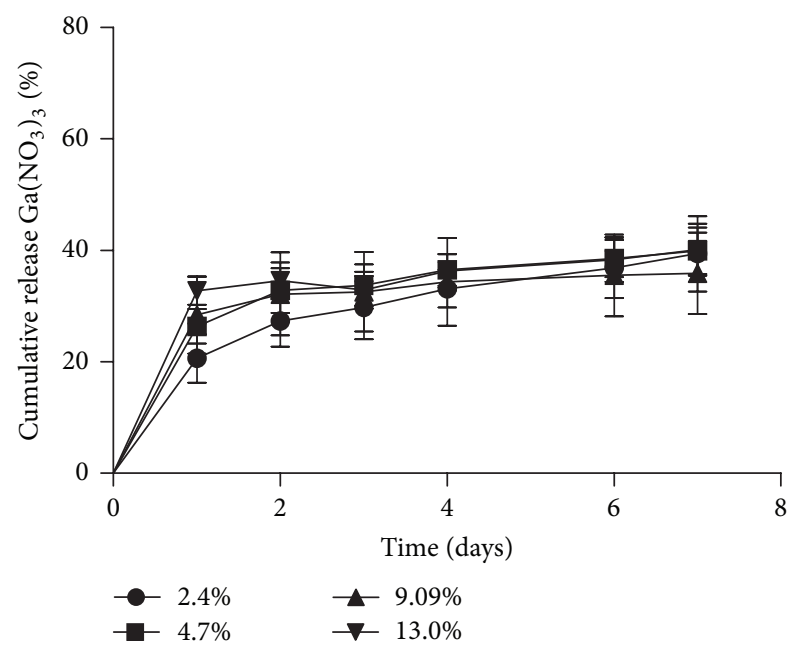

(d)

Figure 2: Characterization of $\mathrm{Ga}\left(\mathrm{NO}_{3}\right)_{3}$ release kinetics from $\mathrm{PMMA}$ and $\mathrm{CaSO}_{4}$ beads. Absolute release of $\mathrm{Ga}\left(\mathrm{NO}_{3}\right)_{3}$ from PMMA (a) and $\mathrm{CaSO}_{4}$ (b) beads, loaded at 2.4, 4.7, 9.09, and 13\% (w/w), over 7 days performed in PBS is shown. The percent cumulative release of the total amount of $\mathrm{Ga}\left(\mathrm{NO}_{3}\right)_{3}$ (by weight) loaded into PMMA (c) and $\mathrm{CaSO}_{4}$ (d) beads is shown. Values are reported as the mean $\pm \mathrm{SD}$ of $n=3$ samples.

biofilm formation and orthopaedic infections, we also evaluated the effectiveness of $\mathrm{Ga}\left(\mathrm{NO}_{3}\right)_{3}$ loaded PMMA and $\mathrm{CaSO}_{4}$ beads to hinder bacterial surface colonization. The incorporation of $\mathrm{Ga}\left(\mathrm{NO}_{3}\right)_{3}$ into PMMA markedly reduced bacteria colonization at days 1 and 3 for $S$. aureus and $S$. epidermidis and up to 7 days for $S$. epidermidis (Figures $4(\mathrm{a})$ and $4(\mathrm{~b}))$. In contrast, incorporation of $\mathrm{Ga}\left(\mathrm{NO}_{3}\right)_{3}$ into $\mathrm{CaSO}_{4}$ at even the highest concentrations was only observed to inhibit colonization of $S$. aureus after 1 day, but not thereafter (Figure 4(c)). Loading of $\mathrm{Ga}\left(\mathrm{NO}_{3}\right)_{3} \geq 4.7 \%$ (w/w) into $\mathrm{CaSO}_{4}$ was observed to significantly reduce colonization of the bead surface by S. epidermidis up to the 7 days evaluated (Figure 4(d)).

3.5. Activity of $\mathrm{Ga}\left(\mathrm{NO}_{3}\right)_{3}$ Loaded PMMA Beads on Established Staphylococcal Biofilms. Given the ability of $\mathrm{Ga}\left(\mathrm{NO}_{3}\right)_{3}$ loaded beads to reduce bacterial colonization, we assessed whether $\mathrm{Ga}\left(\mathrm{NO}_{3}\right)_{3}$ loaded beads also retained activity against established biofilms of $S$. aureus and S. epidermidis. Following the $24 \mathrm{~h}$ exposure of the preformed biofilms to $\mathrm{Ga}\left(\mathrm{NO}_{3}\right)_{3}$ loaded PMMA beads resulted in a 2- to 4-log reduction of viable bacteria within S. aureus and S. epidermidis biofilms compared to untreated controls, which was highly dependent on the percentage loaded into PMMA (Figure 5(a)). Likewise, $\mathrm{CaSO}_{4}$ loaded beads were observed to have a 2- to 3-log reduction of viable bacteria (Figure 5(b)).

\section{Discussion}

Orthopaedic related infections continue to be a significant complication, contributing to the increased overall healthcare associated costs as well as patient associated morbidity [1, $3,6,7]$. Currently, the guidelines for clinical management of such infections include surgical treatment combined with systemic and/or local antimicrobial therapy. However, the emergence of antimicrobial resistance in addition to the ability of bacteria to develop and persist within biofilms has been shown to limit the effectiveness of this intervention $[4,11,12,20]$, highlighting the need for the development of novel treatment strategies to address this growing clinical challenge. Recently, use of the nonreducible iron analog gallium(III), as the salt $\mathrm{Ga}\left(\mathrm{NO}_{3}\right)_{3}$, has been shown to have 


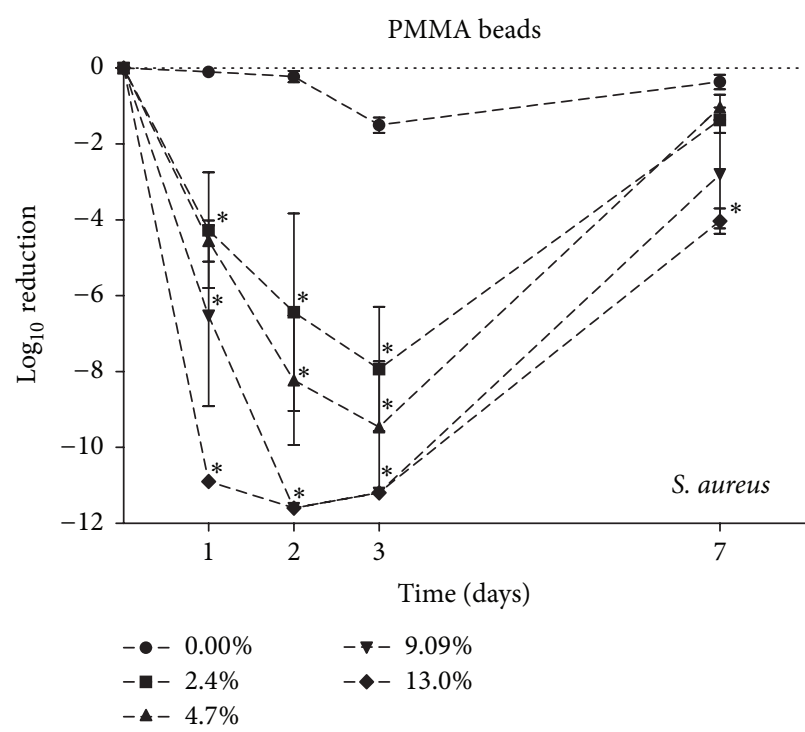

(a)

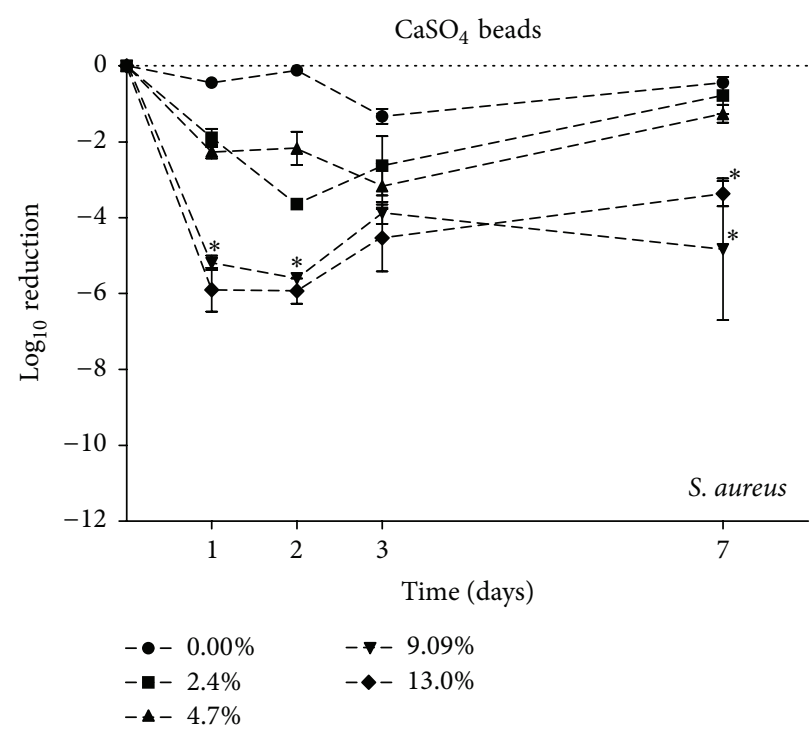

(c)

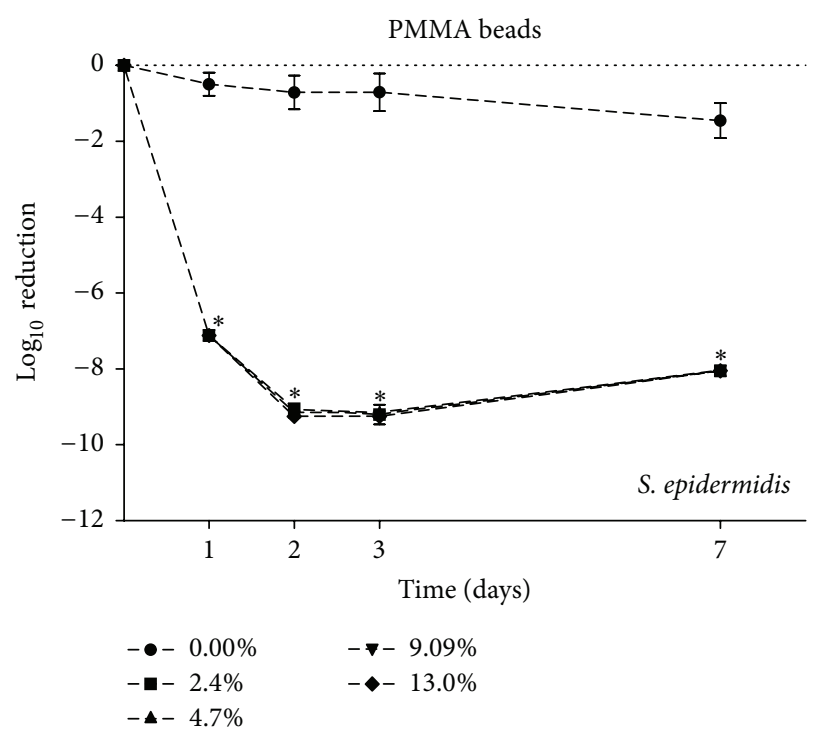

(b)

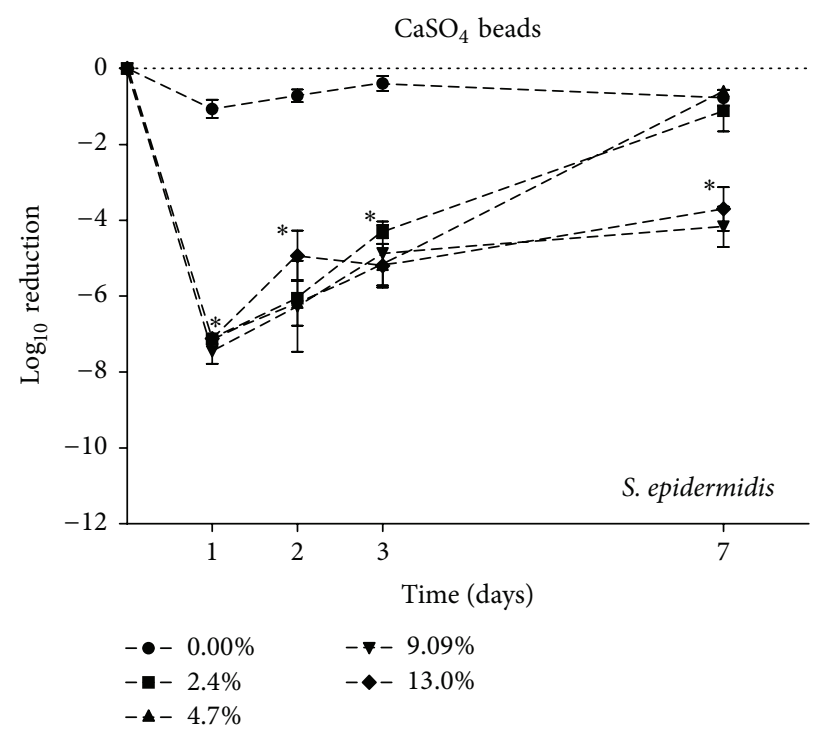

(d)

Figure 3: Activity of $\mathrm{Ga}\left(\mathrm{NO}_{3}\right)_{3}$ loaded $\mathrm{PMMA}$ and $\mathrm{CaSO}_{4}$ beads on planktonic bacteria. Antimicrobial activity of $\mathrm{PMMA}$ (a-b) and CaSO (c-d) loaded $\mathrm{Ga}\left(\mathrm{NO}_{3}\right)_{3}$ beads on bacterial cultures of S. aureus ATCC 12913 and S. epidermidis ATCC 12228 over time. Data are expressed as $\log$ reduction relative to empty (0.0\%) $\mathrm{PMMA} \mathrm{CaSO}_{4}$ beads. Values are reported as the mean $\pm \mathrm{SD}$. Statistical analysis was performed using an analysis of variance (ANOVA) with Dunnett's post hoc test; $*$ indicates $p<0.05$ relative to control.

antimicrobial activity against both Gram positive and Gram negative bacteria in vitro and in vivo [24-26, 34, 35]. While $\mathrm{Ga}\left(\mathrm{NO}_{3}\right)_{3}$ has been approved by the FDA for the treatment of pathological bone loss disorders [28-30], the direct use for treatment of orthopaedic related infections, to our knowledge, has not been evaluated. Therefore, the goal of this study was to assess whether $\mathrm{Ga}\left(\mathrm{NO}_{3}\right)_{3}$ could be incorporated into and released from PMMA and $\mathrm{CaSO}_{4}$ beads for local delivery into wounds as a potential treatment strategy for orthopaedic related infections.

Given the limitations of this treatment modality, recently there has been a resurgence of efforts to optimize this intervention through use and/or incorporation of unique antimicrobial agents alone or as combinations [4, 41, 42], as well as experimental strategies using various compounds with antimicrobial activities [43-45]. Although these approaches may offer a direct benefit to currently used antimicrobials, the threat of antimicrobial resistance continues to be a major limiting factor; moreover for those experimental strategies the likelihood of their direct clinical use would be limited and not available for some time. Due to the critical role of ferric iron to both normal physiology and virulence for bacteria, the use of $\mathrm{Ga}\left(\mathrm{NO}_{3}\right)_{3}$ has been shown to have significant antimicrobial activity against a number of clinically relevant bacteria, including Staphylococcus spp., P. aeruginosa, and A. baumannii [24-26]. Bone cements, including PMMA and 


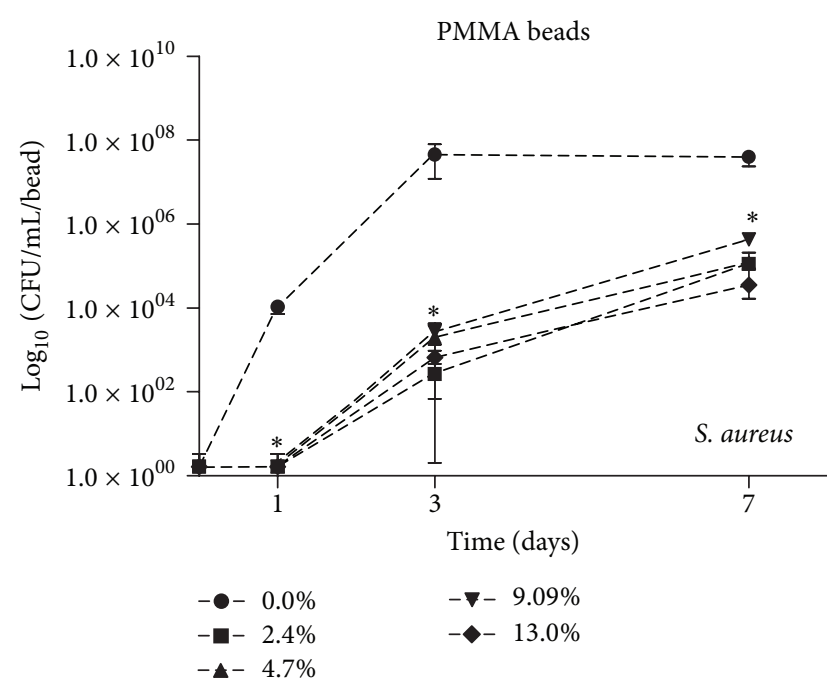

(a)

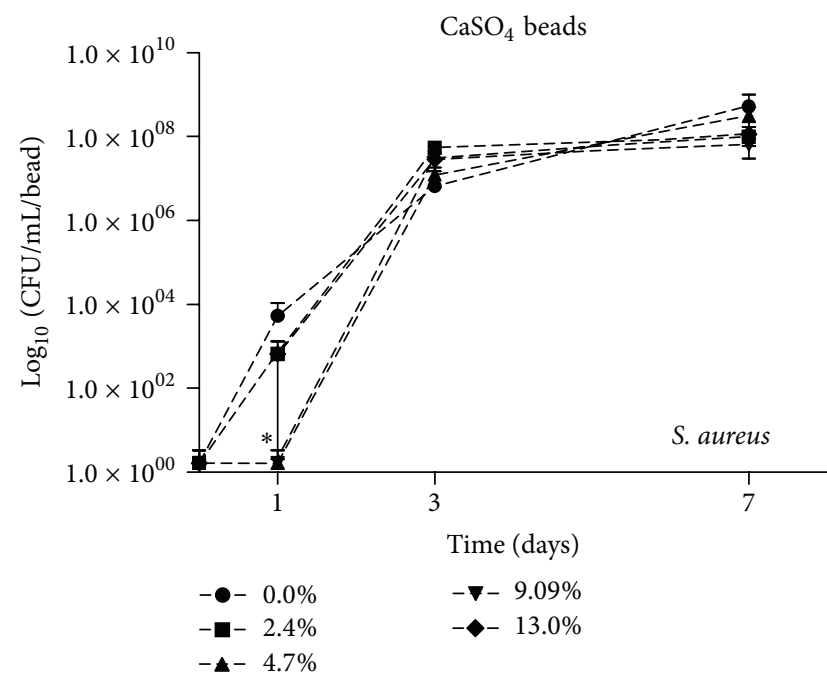

(c)

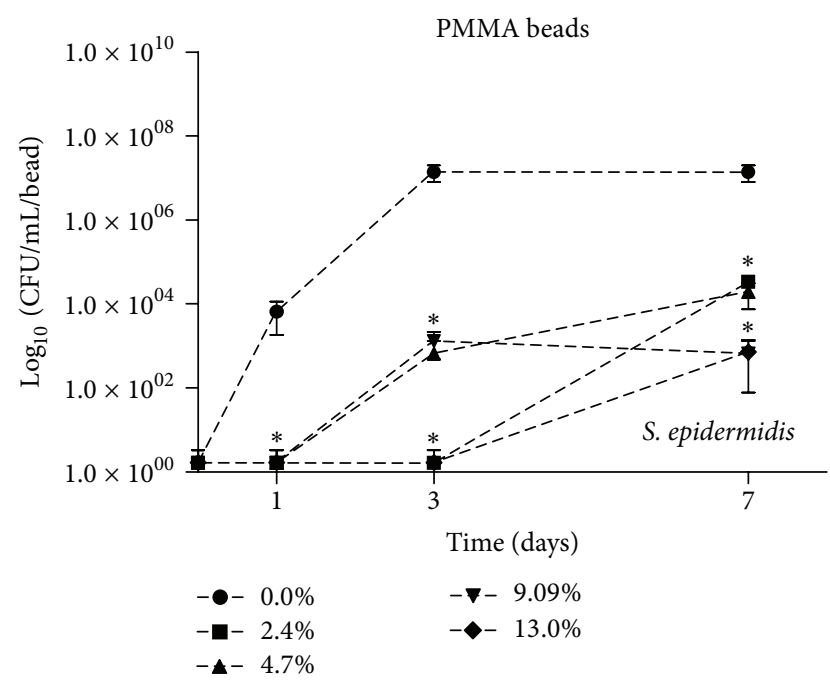

(b)

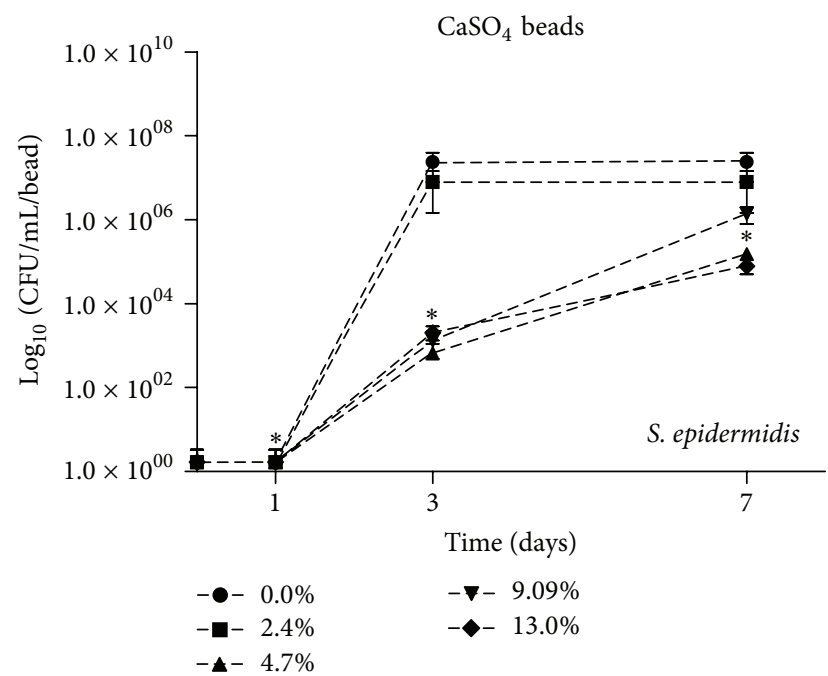

(d)

FIGURE 4: Effect of $\mathrm{Ga}\left(\mathrm{NO}_{3}\right)_{3}$ incorporation on bacterial colonization of PMMA and $\mathrm{CaSO}_{4}$. Colonization of $\mathrm{Ga}\left(\mathrm{NO}_{3}\right)_{3}$ loaded PMMA (a-b) or $\mathrm{CaSO}_{4}$ (c-d), 2.4\%, 4.7\%, 9.09\%, and 13.0\% (w/w), by S. aureus ATCC 12913 and S. epidermidis ATCC 12228 over time, as determined by $\mathrm{CFU}$ counts $\left(\log _{10} \mathrm{CFU} / \mathrm{mL}\right.$ per bead). Data is representative of mean $\pm \mathrm{SD}$. Statistical analysis was performed using an analysis of variance (ANOVA) with Dunnett's post hoc test; $*$ indicates $p<0.05$ relative to control.

$\mathrm{CaSO}_{4}$, are commonly used for local delivery to infected sites to achieve high local concentrations. While these two different carriers offer certain advantages over the other, a major limiting factor is the compatibility of the antimicrobial and/or agent being incorporated $[1,19]$. As demonstrated in Figure 2, herein we showed that $\mathrm{Ga}\left(\mathrm{NO}_{3}\right)_{3}$ was compatible for incorporation into and release from both PMMA and $\mathrm{CaSO}_{4}$. Similar to the release of other previously characterized antibiotics from PMMA [16, 18, 46, 47], release of $\mathrm{Ga}\left(\mathrm{NO}_{3}\right)_{3}$ was characterized by a large initial burst, with mean detectable concentrations between 300 and $1500 \mu \mathrm{M}$, followed by a sustained release over the seven-day period. For PMMA, incorporation of the lower percentages, 2.4$4.7 \%(\mathrm{w} / \mathrm{w})$, was observed to have a greater cumulative release (59\% and $37 \%$, resp.) compared to those beads loaded with the higher percentages (23-25\%). Notably, although $\mathrm{Ga}\left(\mathrm{NO}_{3}\right)_{3}$ release was also observed from $\mathrm{CaSO}_{4}$, cumulative release was much lower in comparison (21-28\%) and not observed to increase with increasing amount of $\mathrm{Ga}\left(\mathrm{NO}_{3}\right)_{3}$ incorporated. Although the exact reasons for this are not entirely clear, there is a possibility that $\mathrm{CaSO}_{4}$ may have interacted with the gallium and subsequently inhibiting its release. From this assessment of elution kinetics alone, our results indicate that PMMA may be a more suitable carrier for local delivery of $\mathrm{Ga}\left(\mathrm{NO}_{3}\right)_{3}$. Of note, while no effects of incorporation of $\mathrm{Ga}\left(\mathrm{NO}_{3}\right)_{3}$ on setting time were observed with $\mathrm{CaSO}_{4}$ directly, incorporation of increasing concentrations of $\mathrm{Ga}\left(\mathrm{NO}_{3}\right)_{3}(\geq 9.09 \% \mathrm{w} / \mathrm{w})$ into PMMA did extend the curing time significantly ( $\sim$ hour). Because antibiotic impregnated beads are prepared during surgical procedures, 

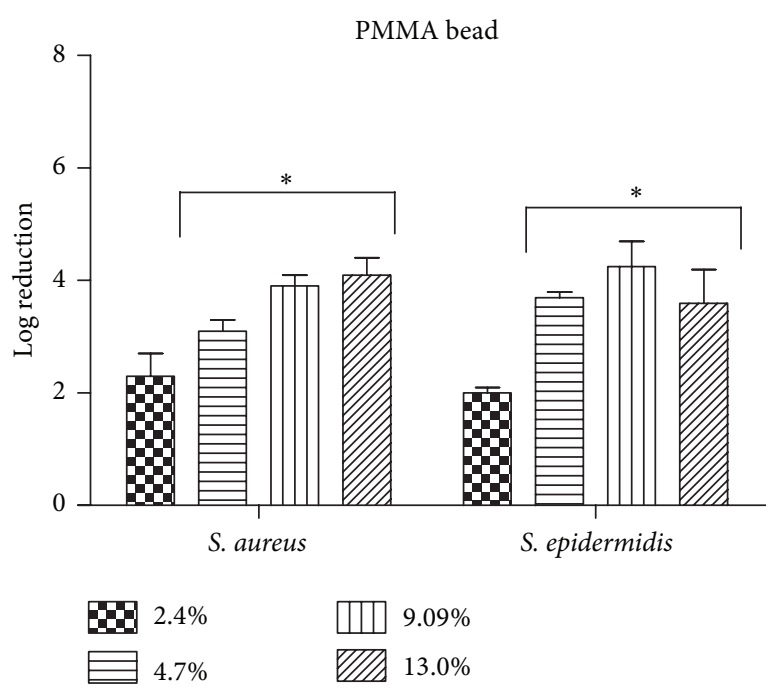

(a)

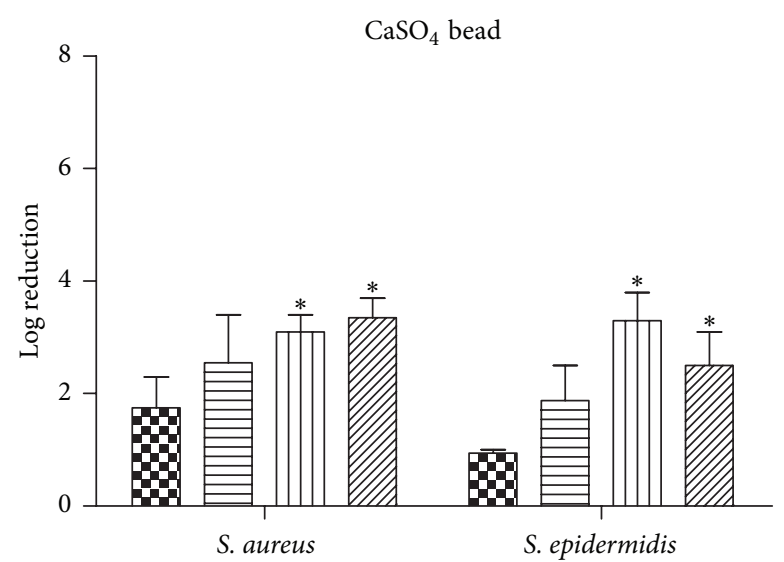

$\begin{array}{ll}\text { D. } 2.4 \% & \text { Ш } 9.09 \% \\ \text { E.7\% } & \text { WIIt } 13.0 \%\end{array}$

(b)

Figure 5: Activity of $\mathrm{Ga}\left(\mathrm{NO}_{3}\right)_{3}$ loaded PMMA beads on established biofilms. Effects of $\mathrm{Ga}\left(\mathrm{NO}_{3}\right)_{3}$ loaded (a) $\mathrm{PMMA}$ and (b) CaSO 4 beads (\% w/w) on established biofilms of S. aureus ATCC 12913 and S. epidermidis ATCC 12228 following overnight exposure. Data is expressed as the $\log$ reductions (mean $\pm \mathrm{SD}$ ) relative to biofilms treated with unloaded control beads. Statistical analysis was performed using an analysis of variance (ANOVA) with Dunnett's post hoc test; $*$ indicates $p<0.05$ relative to control.

just prior to placement within wounds, our observations indicate potential limitations to the use of the $\mathrm{Ga}\left(\mathrm{NO}_{3}\right)_{3}$ with PMMA, in particular concentrations $>9.09 \%$. Importantly, while this is the first study to evaluate the incorporation and release of $\mathrm{Ga}\left(\mathrm{NO}_{3}\right)_{3}$ from bone cements, along the lines of our findings are previous reports showing the utility of bone cements, in particular PMMA, for delivery of antimicrobial agents other than antibiotics, including antimicrobial peptides [44] and antiseptics, such as chlorhexidine and quaternary ammonium compounds [45, 48], demonstrating the compatibility of these materials for use with various types of agents, including $\mathrm{Ga}\left(\mathrm{NO}_{3}\right)_{3}$ despite limitations.

To be an effective treatment, agents incorporated into PMMA or $\mathrm{CaSO}_{4}$ should be appropriate for the organism(s) suspected of causing the infection while also being eluted locally at concentrations sufficient to achieve antimicrobial activity. Consistent with results from the release kinetics studies, the $\mathrm{Ga}\left(\mathrm{NO}_{3}\right)_{3}$ loaded PMMA and $\mathrm{CaSO}_{4}$ beads were observed to have antimicrobial activity against the planktonic cultures of $S$. aureus and S. epidermidis, as demonstrated in Figure 3. Antimicrobial activity of the $\mathrm{Ga}\left(\mathrm{NO}_{3}\right)_{3}$ loaded beads was observed to be most effective during the first 3 days, coinciding with the higher elutions of gallium(III) well above the inhibitory concentration against planktonic bacteria, but rapidly losing activity at 7 days, coinciding with release of levels of gallium(III) at levels below this $(\leq 13 \mu \mathrm{M})$. In contrast to the antimicrobial activity observed with the gallium loaded PMMA beads, the antimicrobial activities of the gallium loaded $\mathrm{CaSO}_{4}$ beads was much more variable demonstrating limited activity against the bacteria tested herein as compared to PMMA. As indicated above, the differences in antimicrobial activity of $\mathrm{Ga}\left(\mathrm{NO}_{3}\right)_{3}$ may in part have been explained by interactions of the gallium with
$\mathrm{CaSO}_{4}$, thereby limiting activity, which would be consistent with the lower cumulative release gallium as well as the reduced antimicrobial activity despite detection of released gallium. Our results demonstrating the activity of $\mathrm{Ga}\left(\mathrm{NO}_{3}\right)_{3}$ against staphylococcal species are in line with previous studies $[25,26]$ and demonstrate the utility of a treatment modality utilizing $\mathrm{Ga}\left(\mathrm{NO}_{3}\right)_{3}$ as a treatment strategy for orthopaedic infections.

While antibiotic-loaded bone cements have been shown to be highly effective against planktonic bacteria, use of this treatment modality against biofilms are often limited $[4,18$, 49]. This is partly due to the reduced metabolic activity of bacteria within biofilms, limiting the activity of most available antimicrobial agents as the main mechanisms of action target actively dividing cells, and the production of an extracellular polymeric matrix surrounding the community, limiting the diffusion of antibiotics into the biofilm [50,51]. Because of the association between biofilms and establishment of orthopaedic infections [4] we also evaluated whether the $\mathrm{Ga}\left(\mathrm{NO}_{3}\right)_{3}$ loaded beads could limit bacterial colonization (i.e., biofilm formation) of beads; moreover we assessed whether they retained activity against established bacterial biofilms. As demonstrated herein, the $\mathrm{Ga}\left(\mathrm{NO}_{3}\right)_{3}$ loaded PMMA beads, and to a lesser extent the gallium loaded $\mathrm{CaSO}_{4}$ beads, were observed to reduce bacterial colonization. These findings are particularly important for PMMA, as the beads are nonabsorbable and potentially can become a foreign body that is subject to colonization by bacteria following elution of the incorporated agent [36]. While the ability of $\mathrm{Ga}\left(\mathrm{NO}_{3}\right)_{3}$ beads to limit bacterial colonization did diminish over time, our findings are similar to those observed for antibiotic loaded beads, including vancomycin and tobramycin [20]. Importantly, and in contrast to in vivo 
settings, the model used to evaluate surface colonization was performed under highly stringent conditions with daily subjections to bacterial inoculums $\left(\sim 10^{6}\right)$, which would likely be much greater than that encountered within a wound containing a single infective dose. Future studies evaluating colonization under in vivo conditions are warranted given the limitations of our in vitro study.

In addition to the antimicrobial activity against planktonic bacteria, $\mathrm{Ga}\left(\mathrm{NO}_{3}\right)_{3}$ released from PMMA and $\mathrm{CaSO}_{4}$ (Figure 5) was observed to have activity against preformed biofilms of $S$. aureus and S. epidermidis. While antimicrobial activity was observed against established biofilms, the effects in comparison to those on planktonic bacteria were markedly reduced, as indicated by the lower log reductions in bacteria, highlighting the issues with treating biofilms. Although the exposure to $\mathrm{Ga}\left(\mathrm{NO}_{3}\right)_{3}$ released from PMMA as well $\mathrm{CaSO}_{4}$ did not completely eradicate bacteria within the biofilms, our findings demonstrate that $\mathrm{Ga}\left(\mathrm{NO}_{3}\right)_{3}$ does retain some activity against biofilms in addition to the planktonic bacteria. This is particularly important because biofilms are thought to play a major role in surgical site infections $[52,53]$.

While our study provided preliminary evidence indicating the compatibility with bone cements and potential use of $\mathrm{Ga}\left(\mathrm{NO}_{3}\right)_{3}$ for treatment of orthopaedic related infections, our current study does have several limitations. First, this study was entirely conducted in vitro under ideal conditions that do not accurately recapitulate in vivo conditions. As such, to extend the impact of these findings, the results from this study require further evaluation to determine the effectiveness of $\mathrm{Ga}\left(\mathrm{NO}_{3}\right)_{3}$ impregnated PMMA and $\mathrm{CaSO}_{4}$ beads to reduce microbial burden within an in vivo environment. Secondly, although antimicrobial activity following exposure to $\mathrm{Ga}\left(\mathrm{NO}_{3}\right)_{3}$ was observed against planktonic, and to a lesser extent against established biofilms of $S$. aureus and S. epidermidis, it is important to note that this activity was largely dose-dependent and did not result in sterility. This poses a particular clinical problem, as those organisms remaining following treatment could contribute to relapse of infection within the surgical sites. In light of recent studies demonstrating enhanced activity of conventional antimicrobials in the $\mathrm{Ga}\left(\mathrm{NO}_{3}\right)_{3}$, future studies evaluating the use of $\mathrm{Ga}\left(\mathrm{NO}_{3}\right)_{3}$ as a combined therapy, rather than a monotherapy, could address this limitation and extend its clinical applications [34]. A third limitation of this study was the fact that we only evaluated incorporation and release from a single type of PMMA and $\mathrm{CaSO}_{4}$. As differences in elution kinetics have been observed between the different types of commercially available bone cements [54,55], it may be relevant to evaluate release of $\mathrm{Ga}\left(\mathrm{NO}_{3}\right)_{3}$ from different sources to identify optimal delivery devices for release into surgical sites. Lastly, while $\mathrm{Ga}\left(\mathrm{NO}_{3}\right)_{3}$ is currently approved for therapy of cancer-related hypercalcemia, the current therapeutic regimens, based on intravenous infusion, allow for serum levels of $10-20 \mu \mathrm{M}[29,30]$. Based on the studies herein, these levels would be ineffective, requiring levels much higher for achieving antimicrobial activity against $S$. aureus and $S$. epidermidis. While there have been studies extensively evaluating and determining $\mathrm{Ga}\left(\mathrm{NO}_{3}\right)_{3}$ to have minimal toxicity in vitro, the much higher levels of $\mathrm{Ga}\left(\mathrm{NO}_{3}\right)_{3}$ from PMMA and $\mathrm{CaSO}_{4}$ well above those levels previously tested warrant further investigation to evaluate biocompatibility and effect on cell function, specifically on osteoblasts and osteoclasts, to determine the limitations of direct application to infected surgical sites.

\section{Conclusions}

The use of antibiotic loaded bone cements is a standard of care used for the prevention and/or treatment of orthopaedic infections. Herein, we show that $\mathrm{Ga}\left(\mathrm{NO}_{3}\right)_{3}$ can be loaded into and eluted from PMMA and $\mathrm{CaSO}_{4}$ at concentrations effective against both planktonic and biofilms of Staphylococcus spp., commonly associated with orthopaedic related infections. Collectively, our in vitro findings suggest that local delivery of $\mathrm{Ga}\left(\mathrm{NO}_{3}\right)_{3}$ may be an effective strategy for the prevention and/or treatment of orthopaedic related infections. Future studies utilizing animal models are needed to fully characterize the clinical role for this treatment modality.

\section{Disclaimer}

The views expressed herein are the views of the authors and do not reflect the official policy or position of the Department of the Army, Department of the Air Force, Department of Defense, or the US Government. The authors are employees of the US Government and this work was prepared as part of their official duties and, as such, there is no copyright to be transferred.

\section{Conflict of Interests}

The authors declare that they have no conflict of interests.

\section{Acknowledgment}

This work was supported by intramural funding from the Combat Casualty Research Program, Medical Research and Materiel Command.

\section{References}

[1] J. H. Calhoun and J. T. Mader, "Antibiotic beads in the management of surgical infections," The American Journal of Surgery, vol. 157, no. 4, pp. 443-449, 1989.

[2] J. S. Gogia, J. P. Meehan, P. E. Di Cesare, and A. A. Jamali, "Local antibiotic therapy in osteomyelitis," Seminars in Plastic Surgery, vol. 23, no. 2, pp. 100-107, 2009.

[3] P. A. W. Ostermann, D. Seligson, and S. L. Henry, "Local antibiotic therapy for severe open fractures. A review of 1085 consecutive cases," Journal of Bone and Joint Surgery Series: B, vol. 77, no. 1, pp. 93-97, 1995.

[4] P. Stoodley, G. D. Ehrlich, P. P. Sedghizadeh et al., "Orthopaedic biofilm infections," Current Orthopaedic Practice, vol. 22, no. 6, pp. 558-563, 2011.

[5] J. G. Belisle, J. C. Wenke, and C. A. Krueger, "Return-to-duty rates among US military combat-related amputees in the global 
war on terror: job description matters," Journal of Trauma and Acute Care Surgery, vol. 75, no. 2, pp. 279-286, 2013.

[6] T. C. Burns, D. J. Stinner, A. W. Mack et al., "Microbiology and injury characteristics in severe open tibia fractures from combat," Journal of Trauma and Acute Care Surgery, vol. 72, no. 4, pp. 1062-1067, 2012.

[7] C. A. Krueger, J. C. Wenke, and J. R. Ficke, "Ten years at war: comprehensive analysis of amputation trends," Journal of Trauma and Acute Care Surgery, vol. 73, no. 6, supplement 5, pp. S438-S444, 2012.

[8] D. J. Tennent, J. C. Wenke, J. C. Rivera, and C. A. Krueger, "Characterisation and outcomes of upper extremity amputations," Injury, vol. 45, no. 6, pp. 965-969, 2014.

[9] P. D. P. Lew and P. F. A. Waldvogel, "Osteomyelitis," The Lancet, vol. 364, no. 9431, pp. 369-379, 2004.

[10] K. V. Brown, C. K. Murray, and J. C. Clasper, "Infectious complications of combat-related mangled extremity injuries in the British military," Journal of Trauma, vol. 69, supplement 1, pp. S109-S114, 2010.

[11] P. Anguita-Alonso, A. D. Hanssen, D. R. Osmon, A. Trampuz, J. M. Steckelberg, and R. Patel, "High rate of aminoglycoside resistance among staphylococci causing prosthetic joint infection," Clinical Orthopaedics and Related Research, vol. 439, pp. 43-47, 2005.

[12] W. Witte, "Antibiotic resistance in gram-positive bacteria: epidemiological aspects," Journal of Antimicrobial Chemotherapy, vol. 44, supplement A, pp. 1-9, 1999.

[13] H. W. Buchholz and H. Engelbrecht, "Depot effects of various antibiotics mixed with Palacos resins," Der Chirurg; Zeitschrift fur alle Gebiete der operativen Medizen, vol. 41, no. 1, pp. 511$515,1970$.

[14] S. L. Henry and K. P. Galloway, "Local antibacterial therapy for the management of orthopaedic infections: pharmacokinetic considerations," Clinical Pharmacokinetics, vol. 29, no. 1, pp. 3645, 1995.

[15] G. Josefsson and L. Kolmert, "Prophylaxis with systematic antibiotics versus gentamicin bone cement in total hip arthroplasty: a ten-year survey of 1688 hips," Clinical Orthopaedics and Related Research, no. 292, pp. 210-214, 1993.

[16] A. C. Perry, M. S. Rouse, Y. Khaliq et al., "Antimicrobial release kinetics from polymethylmethacrylate in a novel continuous flow chamber," Clinical Orthopaedics and Related Research, vol. 403, pp. 49-53, 2002.

[17] B. Picknell, L. Mizen, and R. Sutherland, "Antibacterial activity of antibiotics in acrylic bone cement," The Journal of Bone \& Joint Surgery -British Volume, vol. 59, no. 3, pp. 302-307, 1977.

[18] S. J. McConoughey, R. P. Howlin, J. Wiseman, P. Stoodley, and J. H. Calhoun, "Comparing PMMA and calcium sulfate as carriers for the local delivery of antibiotics to infected surgical sites," Journal of Biomedical Materials Research Part B Applied Biomaterials, vol. 130, no. 4, pp. 870-877, 2015.

[19] K. J. Wilson, G. Cierny, K. R. Adams, and J. T. Mader, "Comparative evaluation of the diffusion of tobramycin and cefotaxime out of antibiotic-impregnated polymethylmethacrylate beads," Journal of Orthopaedic Research, vol. 6, no. 2, pp. 279-286, 1988.

[20] R. P. Howlin, M. J. Brayford, J. S. Webb, J. J. Cooper, S. S. Aiken, and P. Stoodley, "Antibiotic-loaded synthetic calcium sulfate beads for prevention of bacterial colonization and biofilm formation in periprosthetic infections," Antimicrobial Agents and Chemotherapy, vol. 59, no. 1, pp. 111-120, 2015.
[21] E. P. Skaar, "The battle for iron between bacterial pathogens and their vertebrate hosts," PLoS Pathogens, vol. 6, no. 8, Article ID e1000949, 2010.

[22] K. P. Haley and E. P. Skaar, "A battle for iron: host sequestration and Staphylococcus aureus acquisition," Microbes and Infection, vol. 14, no. 3, pp. 217-227, 2012.

[23] N. D. Hammer and E. P. Skaar, "Molecular mechanisms of Staphylococcus aureus iron acquisition," Annual Review of Microbiology, vol. 65, pp. 129-147, 2011.

[24] C. Bonchi, F. Imperi, F. Minandri, P. Visca, and E. Frangipani, "Repurposing of gallium-based drugs for antibacterial therapy," BioFactors, vol. 40, no. 3, pp. 303-312, 2014.

[25] A. B. Kelson, M. Carnevali, and V. Truong-Le, "Gallium-based anti-infectives: targeting microbial iron-uptake mechanisms," Current Opinion in Pharmacology, vol. 13, no. 5, pp. 707-716, 2013.

[26] I. Stojiljkovic, V. Kumar, and N. Srinivasan, "Non-iron metalloporphyrins: potent antibacterial compounds that exploit haem/Hb uptake systems of pathogenic bacteria," Molecular Microbiology, vol. 31, no. 2, pp. 429-442, 1999.

[27] M. G. Thompson, B. W. Corey, Y. Si, D. W. Craft, and D. V. Zurawski, "Antibacterial activities of iron chelators against common nosocomial pathogens," Antimicrobial Agents and Chemotherapy, vol. 56, no. 10, pp. 5419-5421, 2012.

[28] L. R. Bernstein, "Mechanisms of therapeutic activity for gallium," Pharmacological Reviews, vol. 50, no. 4, pp. 665-682, 1998.

[29] C. R. Chitambar, "Medical applications and toxicities of gallium compounds," International Journal of Environmental Research and Public Health, vol. 7, no. 5, pp. 2337-2361, 2010.

[30] P. Collery, B. Keppler, C. Madoulet, and B. Desoize, “Gallium in cancer treatment," Critical Reviews in Oncology/Hematology, vol. 42, no. 3, pp. 283-296, 2002.

[31] C. E. Arnold, A. Bordin, S. D. Lawhon, M. C. Libal, L. R. Bernstein, and N. D. Cohen, "Antimicrobial activity of gallium maltolate against Staphylococcus aureus and methicillinresistant S. aureus and Staphylococcus pseudintermedius: an in vitro study," Veterinary Microbiology, vol. 155, no. 2-4, pp. 389394, 2012.

[32] D. Baldoni, A. Steinhuber, W. Zimmerli, and A. Trampuz, "In vitro activity of gallium maltolate against staphylococci in logarithmic, stationary, and biofilm growth phases: comparison of conventional and calorimetric susceptibility testing methods," Antimicrobial Agents and Chemotherapy, vol. 54, no. 1, pp. 157163, 2010.

[33] H. Ma, E. T. Darmawan, M. Zhang, L. Zhang, and J. D. Bryers, "Development of a poly(ether urethane) system for the controlled release of two novel anti-biofilm agents based on gallium or zinc and its efficacy to prevent bacterial biofilm formation," Journal of Controlled Release, vol. 172, no. 3, pp. 1035-1044, 2013.

[34] L. C. S. Antunes, F. Imperi, F. Minandri, and P. Visca, "In vitro and in vivo antimicrobial activities of gallium nitrate against multidrug-resistant Acinetobacter baumannii," Antimicrobial Agents and Chemotherapy, vol. 56, no. 11, pp. 5961-5970, 2012.

[35] L. De Léséleuc, G. Harris, R. KuoLee, and W. Chen, "In vitro and in vivo biological activities of iron chelators and gallium nitrate against Acinetobacter baumannii," Antimicrobial Agents and Chemotherapy, vol. 56, no. 10, pp. 5397-5400, 2012.

[36] D. Neut, H. van de Belt, I. Stokroos, J. R. Van Horn, H. C. Van Der Mei, and H. J. Busscher, "Biomaterial-associated infection 
of gentamicin-loaded PMMA beads in orthopaedic revision surgery," Journal of Antimicrobial Chemotherapy, vol. 47, no. 6 , pp. 885-891, 2001.

[37] P. Anguita-Alonso, M. S. Rouse, K. E. Piper, D. J. Jacofsky, D. R. Osmon, and R. Patel, "Comparative study of antimicrobial release kinetics from polymethylmethacrylate," Clinical Orthopaedics \& Related Research, vol. 445, pp. 239-244, 2006.

[38] C. J. Sanchez, S. M. Shiels, D. J. Tennent, S. K. Hardy, C. K. Murray, and J. C. Wenke, "Rifamycin derivatives are effective against staphylococcal biofilms in vitro and elutable from PMMA," Clinical Orthopaedics and Related Research, vol. 473, no. 9, pp. 2874-2884, 2015.

[39] H. Ceri, M. Olson, D. Morck et al., “The MBEC assay system: multiple equivalent biofilms for antibiotic and biocide susceptibility testing," Methods in Enzymology, vol. 337, pp. 377-385, 2001.

[40] D. C. Coraça-Hubér, M. Fille, J. Hausdorfer, K. Pfaller, and M. Nogler, "Evaluation of MBEC-HTP biofilm model for studies of implant associated infections," Journal of Orthopaedic Research, vol. 30, no. 7, pp. 1176-1180, 2012.

[41] P. Peñalba Arias, U. Furustrand Tafin, B. Bétrisey, S. Vogt, A. Trampuz, and O. Borens, "Activity of bone cement loaded with daptomycin alone or in combination with gentamicin or PEG600 against Staphylococcus epidermidis biofilms," Injury, vol. 46, no. 2, pp. 249-253, 2015.

[42] P. Vergidis, S. M. Schmidt-Malan, J. N. Mandrekar, J. M. Steckelberg, and R. Patel, "Comparative activities of vancomycin, tigecycline and rifampin in a rat model of methicillin-resistant Staphylococcus aureus osteomyelitis," Journal of Infection, vol. 70, no. 6, pp. 609-615, 2015.

[43] P. Anguita-Alonso, A. Giacometti, O. Cirioni et al., "RNAIIIinhibiting-peptide-loaded polymethylmethacrylate prevents in vivo Staphylococcus aureus biofilm formation," Antimicrobial Agents and Chemotherapy, vol. 51, no. 7, pp. 2594-2596, 2007.

[44] C. Faber, H. P. Stallmann, D. M. Lyaruu et al., "Release of antimicrobial peptide Dhvar-5 from polymethylmethacrylate beads," Journal of Antimicrobial Chemotherapy, vol. 51, no. 6, pp. 1359-1364, 2003.

[45] M. Mathey, V. Surana, M. Edwards, and J. W. Nicholson, "A preliminary study of the release of quaternary ammonium antimicrobial compounds from acrylic bone cement," Journal of Materials Science: Materials in Medicine, vol. 20, no. 7, pp. 15791583, 2009.

[46] T. Miclau, L. E. Dahners, and R. W. Lindsey, "In vitro pharmacokinetics of antibiotic release from locally implantable materials," Journal of Orthopaedic Research, vol. 11, no. 5, pp. 627-632, 1993.

[47] M. J. Penner, C. P. Duncan, and B. A. Masri, "The in vitro elution characteristics of antibiotic-loaded CMW and Palacos-R bone cements," Journal of Arthroplasty, vol. 14, no. 2, pp. 209-214, 1999.

[48] N. Hiraishi, C. K. Y. Yiu, N. M. King, and F. R. Tay, "Chlorhexidine release and antibacterial properties of chlorhexidineincorporated polymethyl methacrylate-based resin cement," Journal of Biomedical Materials Research-Part B: Applied Biomaterials, vol. 94, no. 1, pp. 134-140, 2010.

[49] J. A. Inzana, E. M. Schwarz, S. L. Kates, and H. A. Awad, "A novel murine model of established Staphylococcal bone infection in the presence of a fracture fixation plate to study therapies utilizing antibiotic-laden spacers after revision surgery," Bone, vol. 72, pp. 128-136, 2015.
[50] J. W. Costerton, P. S. Stewart, and E. P. Greenberg, "Bacterial biofilms: a common cause of persistent infections," Science, vol. 284, no. 5418, pp. 1318-1322, 1999.

[51] T.-F. C. Mah and G. A. O’Toole, "Mechanisms of biofilm resistance to antimicrobial agents," Trends in Microbiology, vol. 9, no. 1, pp. 34-39, 2001.

[52] R. A. Brady, J. G. Leid, J. H. Calhoun, J. W. Costerton, and M. E. Shirtliff, "Osteomyelitis and the role of biofilms in chronic infection," FEMS Immunology and Medical Microbiology, vol. 52, no. 1, pp. 13-22, 2008.

[53] J. W. Costerton, "Biofilm theory can guide the treatment of device-related orthopaedic infections," Clinical Orthopaedics and Related Research, no. 437, pp. 7-11, 2005.

[54] G. Lewis, "Not all approved antibiotic-loaded PMMA bone cement brands are the same: ranking using the utility materials selection concept," Journal of Materials Science: Materials in Medicine, vol. 26, no. 1, article 5388, 2015.

[55] G. Lewis and A. Bhattaram, "Influence of a pre-blended antibiotic (gentamicin sulfate powder) on various mechanical, thermal, and physical properties of three acrylic bone cements," Journal of Biomaterials Applications, vol. 20, no. 4, pp. 377-408, 2006. 

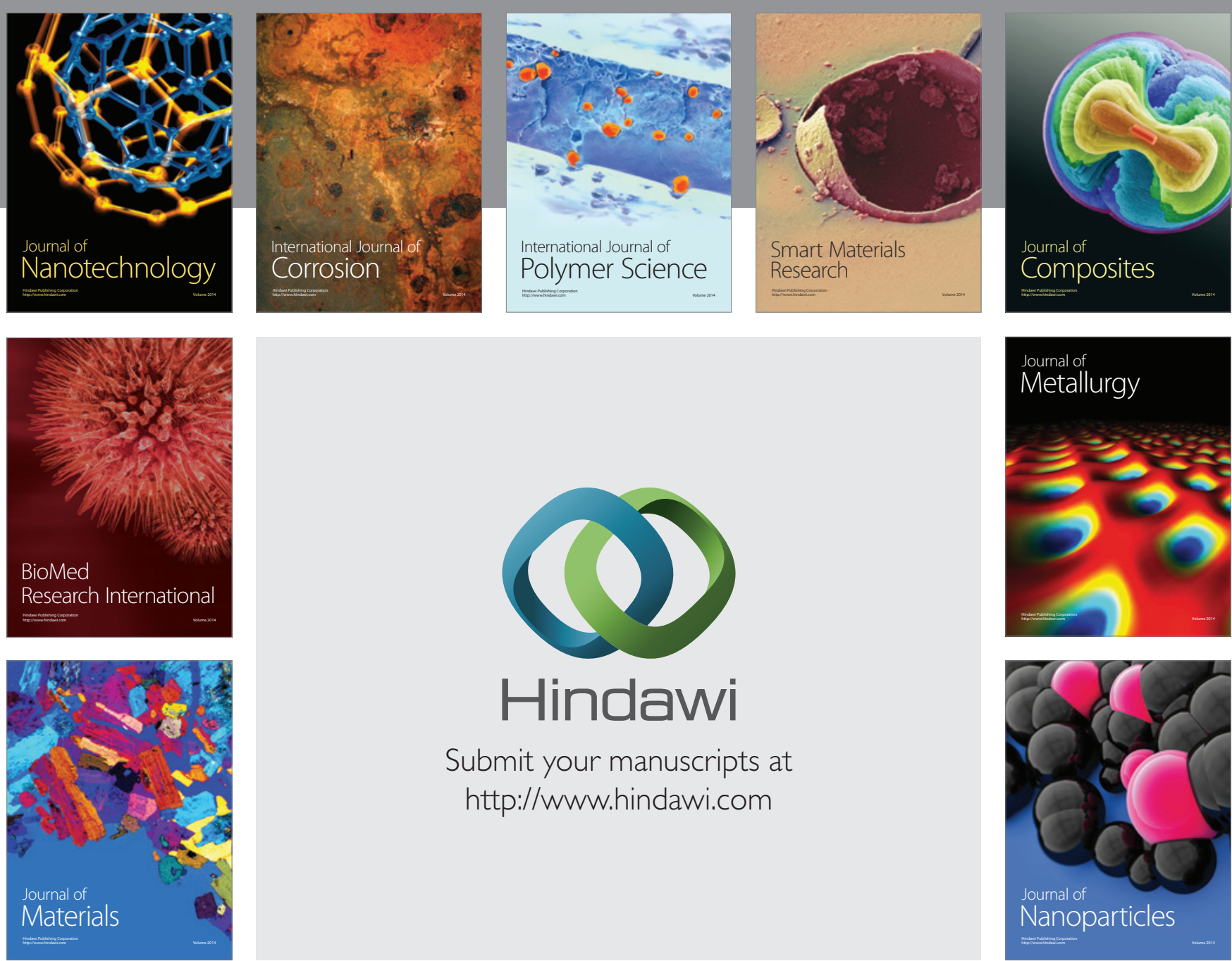

\section{Hindawi}

Submit your manuscripts at

http://www.hindawi.com

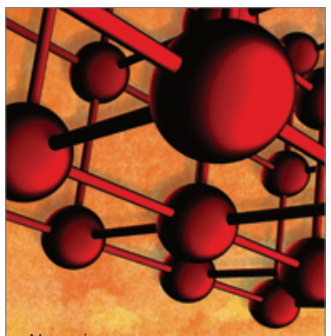

Materials Science and Engineering
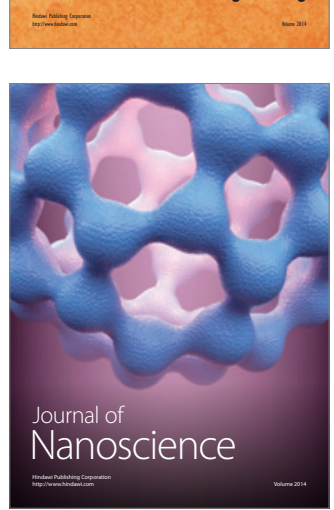
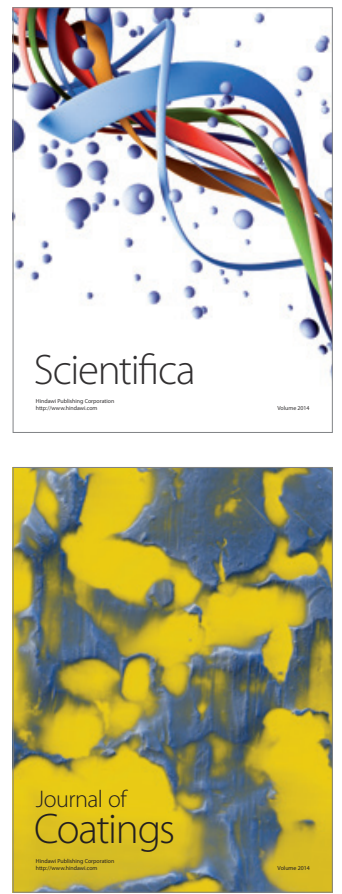
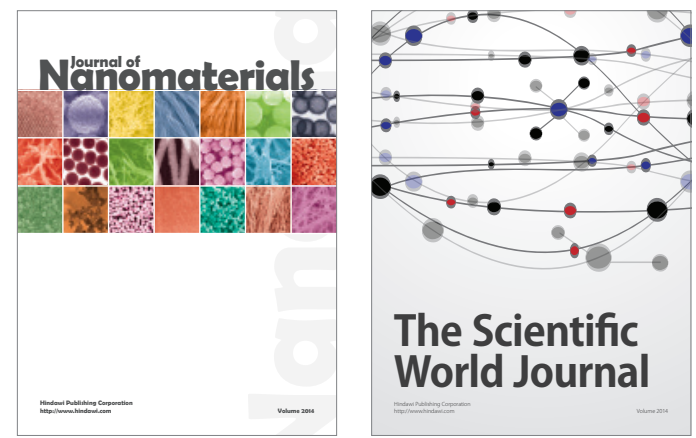

The Scientific World Journal
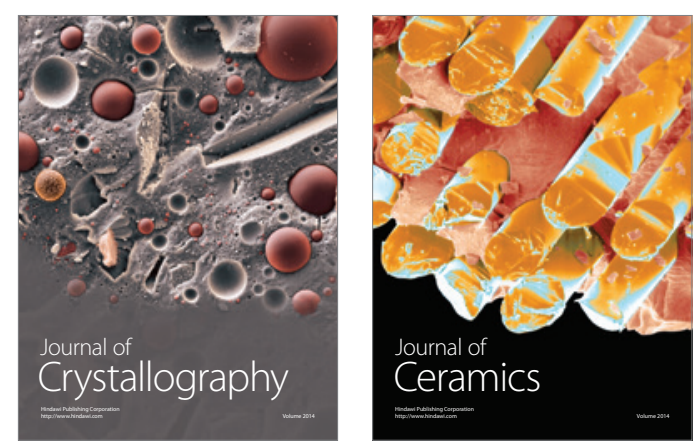
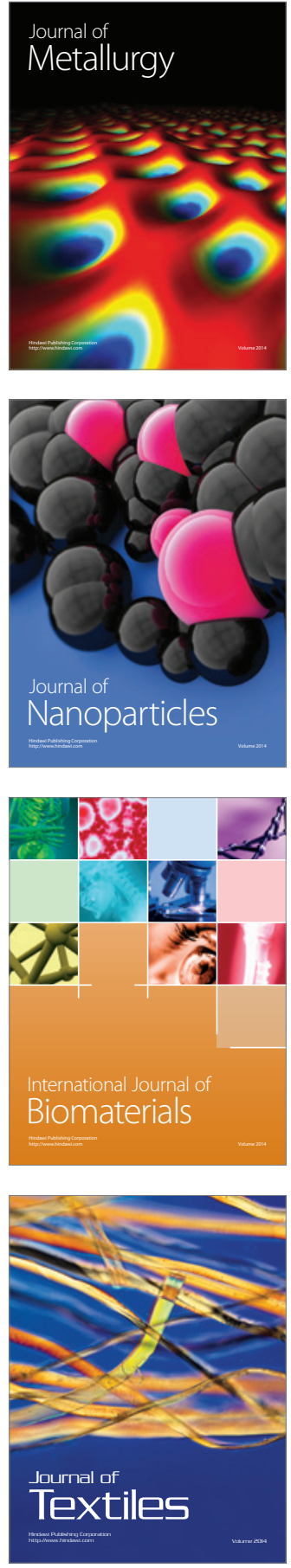